\title{
How Much Have Chinese Investors Invested in Australia?
}

\author{
Kerry Liu ${ }^{1}$
}

\begin{abstract}
Chinese outward direct investment (ODI) in Australia has been debated for many years. Different data sources provide quite different indications of how much Chinese investors have actually invested in Australia. This study analyses each data source's application and limitations, and provides some guidelines on how to interpret and use these data. The findings include: first, although the Australian Bureau of Statistics and Chinese official data measure direct Chinese ODI in Australia, the real value of Chinese capital flow into Australia is greater than these measures. Second, KPMG/University of Sydney and American Enterprise Institute/Heritage Fund data measure contracted value, which may be expected to be higher than the true value of capital flow given the uncertainty of the business environment. Third, as Foreign Investment Review Board data is the value of proposed investment, using this data to measure Chinese ODI in Australia is misleading.
\end{abstract}

\section{Introduction}

Chinese outward direct investment (ODI) in Australia has been a hot topic for debate for many years. For example, during 2008-09, the scale and speed of the surge of Chinese state-owned enterprises' (SOEs') investment in Australia raised the question of whether investments by SOEs require special scrutiny (Drysdale, 2011). Since then, many concerns including job issues, food security issues and so on have been raised about Chinese ODI in Australian public debate (Drysdale et al., 2016). The most recent concern is the possibility that Chinese Government could strategically leverage Chinese investments in critical infrastructure to impede

1 Kerry Liu is an independent scholar of the Chinese economy, kerry.luke@gmail.com. The author would like to thank one anonymous referee and the editor for their helpful comments. 
Australia's national security. The climax of the Australian Government's response to this debate is the establishment of the Critical Infrastructure Centre, announced on 23 January 2017. The main reason given for this is '[given] the shift in our international investment profile, Australia's national critical infrastructure is more exposed than ever to sabotage, espionage and coercion' (Australian Government, 2017). This shift in Australia's investment profile mainly means the rise of Chinese foreign direct investment (FDI) in Australia, evidenced with a string of recent events including the sale of the Port of Darwin to the Chinese-owned Landbridge for AU\$506 million in October 2015, the Treasurer's decision to refuse the sale of the AU\$370-million Kidman cattle property in April 2016 to Chinese investors, and the Treasurer's further refusal of Chinese State Grid's AU\$10-billion bid of AusGrid in August 2016.

Chinese ODI in Australia has attracted extensive attention from a variety of stakeholders including the media. Yet the issue of how much Chinese investors have invested in Australia is a mystery. Media reports often provide conflicting figures, which, sometimes if not always, are puzzling. For example, on 27 February 2017, The Australian announced, 'Chinese investment in Australia soars to \$4.8bn' (Callick, 2017). Around two months later, on 1 May 2017, The Sydney Morning Herald reported, 'Chinese investment in Australia surged 11.7 per cent to $\$ 15.4 \mathrm{~b}$ last year: report' (Scott, 2017). Just eight days later, on 9 May 2017, the Financial Review offered, 'Chinese investment in real estate grows to \$32b: FIRB' (Tan, 2017). So, what is really going on?

With regard to the exact figure of Chinese ODI in Australia, there are three types of data sources. The first is the official statistics from Australian Bureau of Statistics (ABS) and the Department of Commerce, China (DCC). The second is research institutions, including the KPMG/University of Sydney (UniSyd) 'Demystifying Chinese Investment in Australia' series, and the American Enterprise Institute (AEI) and the Heritage Foundation (HF) data. The third is the data released by the Foreign Investment Review Board (FIRB). Each of the above data sources show a different picture of Chinese ODI in Australia. While not trying to give a fourth type of Chinese ODI in Australia data, this study analyses the applications and limitations of each data source, and provides some guidelines on how to interpret and use these data.

\section{Official data: ABS vs DCC data}

In terms of ABS data, the conceptual framework used in compiling Australia's FDI statistics is based on the Balance of Payments and International Investment Position Manual (sixth edition), produced by the International Monetary Fund (IMF, 2009). Accordingly, a foreign direct investor is an entity resident in one economy that has acquired, either directly or indirectly, at least 10 per cent of the voting power of 
a corporation, or equivalent for an unincorporated enterprise, resident in another economy. Furthermore, FDI statistics are presented according to the directional principle rather than asset/liability principle. Under the directional presentation, the direct investment flows and positions are organised according to the direction of the investment for the reporting economy-either outward or inward. So, for a particular country, all flows and positions of direct investors resident in that economy are shown under outward investment and all flows and positions for direct investment enterprises resident in that economy are shown under inward investment. The ABS also mentions how to treat reverse investment, which is when an affiliate invests in its parent. Under the directional presentation, reverse investment is subtracted to derive the amount of total outward or inward investment of the reporting country. So, if a resident parent borrows money from one of its foreign affiliates, this is subtracted in calculating the reporting country's outward investment because it reduces the amount of money that the resident country's parent entity has invested in its foreign affiliates on a net basis. Similarly, if a resident affiliate lends money to its foreign parent, this is subtracted when calculating inward investment because it reduces the amount of money that the foreign parent has invested in the resident country on a net basis. The ABS also notes that the country of residence of the ultimate benefit owner/recipient is not identified, so the country allocation of financial transactions and levels is based on the immediate country of residence (ABS, 2016), suggesting that ABS data may potentially underestimate Chinese flows in Australia. The ABS also includes reinvested earnings and excludes Hong Kong (HK, and Taiwan) from its calculation of Chinese FDI in Australia.

As to the DCC data, the DCC does not explicitly state that it follows the IMF guidelines. However, the DCC does use the same definition of FDI as ABS, including adopting the 10 per cent voting rights criterion. The DCC also adopts the reverse investment concept, which is defined as an affiliate's not more than 10 per cent investment in its parent or resident enterprise. Also, the DCC states that the country allocation of financial transactions and levels is based on the immediate country of residence (DCC, 2010). The DCC also includes reinvested earnings in its calculation of Chinese ODI. So, we can conclude that while there are some differences, such as the DCC's 10 per cent criterion for reverse investment, the methodologies of FDI/ODI statistics of the ABS and the DCC are similar.

Table 1 shows Chinese ODI in Australia based on ABS data and DCC data.

Table 1. Chinese ODI in Australia: ABS data vs DCC data (AU\$ billion)

\begin{tabular}{|l|r|r|r|r|r|r|r|r|r|}
\hline & 2008 & 2009 & 2010 & 2011 & 2012 & 2013 & 2014 & 2015 & 2016 \\
\hline DCC & 2.18 & 3.13 & 1.87 & 3.09 & 2.10 & 3.54 & 4.48 & 4.50 & - \\
\hline ABS & 3.19 & 4.86 & 2.63 & 3.27 & 3.44 & 6.15 & 9.86 & 3.38 & 3.86 \\
\hline
\end{tabular}

Source: Author's summary of ABS and DCC data. 
First, since the ABS excludes HK (and Taiwan) from its calculation of Chinese ODI in Australia, and only considers immediate country of residence, it is highly likely that some Chinese investments in the disguise of HK/Cayman Island/British Virgin Island (BVI) identities enter Australia. Since HK, Cayman Island and BVI are the top three destinations for Chinese ODI (see Table 2), the real amount of Chinese ODI in Australia would thus be higher than the ABS data shows.

Table 2. Top 10 destinations of Chinese ODI by end of 2015 (US\$ billion)

\begin{tabular}{|l|l|l|l|l|l|l|l|l|l|}
\hline HK & $\begin{array}{l}\text { Cayman } \\
\text { Island }\end{array}$ & $\begin{array}{l}\text { British } \\
\text { Virgin } \\
\text { Island }\end{array}$ & USA & Singapore & Australia & Holland & UK & Russia & Canada \\
\hline 656.86 & 62.40 & 51.67 & 40.80 & 31.98 & 28.37 & 20.07 & 16.63 & 14.02 & 8.52 \\
\hline
\end{tabular}

Source: DCC.

Second, comparing ABS data and DCC data shows that ABS data are generally higher than DCC data before 2014. While Chinese private capital flows are dominated by FDI (Hatzvi et al., 2015), this difference may reflect the systematic inaccuracy (underestimation) of DCC data as a result of Chinese investors' longterm intention of trying to escape from capital account control regime.

Third, the year 2015 shows a different picture. In this year, Chinese ODI in Australia significantly decreased from AU\$9.9 billion in 2014 to just AU\$3.4 billion in 2015, according to ABS data. There are possibly two explanations.

- First, the Australian dollar depreciated a lot against USD and RMB in 2015, which means that investment in Australia would suffer exchange rate losses.

- Second, Chinese capital may have mainly flowed to HK in 2015. The People's Bank of China suddenly depreciated its currency against USD by 1.9 per cent on 11 August 2015. This unexpected policy change led Chinese investors (and international investors as well) to think China would join the 'currency war' and further depreciate the RMB to boost its exports (Liu, 2016). As Chinese capital flow seems to be driven by expected changes in the exchange rate (Hatzvi et al., 2015), Chinese investors traditionally use $\mathrm{HK}$ as the primary stop for capital outflow when encountering turmoils such as during 2008-09 and 2015 (Table 3; Prasad \& Wei, 2007).

Table 3. Fraction of Chinese ODI in HK (per cent)

\begin{tabular}{|l|c|c|c|c|c|c|c|c|c|c|}
\hline Year & 2006 & 2007 & 2008 & 2009 & 2010 & 2011 & 2012 & 2013 & 2014 & 2015 \\
\hline $\begin{array}{l}\text { \% of Chinese ODI } \\
\text { invested in HK }\end{array}$ & 32.8 & 51.8 & 69.1 & 63.0 & 56.0 & 47.8 & 58.4 & 58.3 & 57.6 & 61.6 \\
\hline
\end{tabular}

Source: DCC. 


\section{Research institution data: KPMG/UniSyd data vs AEI/HF data}

KPMG/UniSyd started publishing its 'Demystifying Chinese Investment' report series in 2011. However, KPMG/UniSyd reports did not disclose the methodology employed to collect and analyse data until 2013. Starting in 2013, KPMG/UniSyd reports stated that they cover direct investments into Australia made by entities from the People's Republic of China through mergers and acquisitions (M\&A), joint ventures (JVs) and greenfield projects. However, 'greenfield projects' were not mentioned in the 2016 report. ${ }^{2}$ Furthermore, it is not clear how the yearly greenfield investment data are obtained and analysed, but rather 'The University of Sydney and KPMG team obtains raw data on China's ODI from a wide variety of public information sources which are verified, analysed and presented' (KPMG/UniSyd, 2013-2017). KPMG/UniSyd reports also state that their datasets track Chinese investment by subsidiaries or special purpose vehicles based in HK, Singapore and other locations. Moreover, completed deals that are valued below US\$5 million are not included.

The AEI/HF also publishes Chinese ODI data since 2005 (AEI/HF, 2017). In terms of original data source, 'we predate Dealogic for this and use the companies themselves - press releases, Shanghai or Hong Kong exchange disclosures, and the like' (Derek Scissors, AEI/HF data author, personal communication, May 2017). The AEI/HF also publishes Chinese construction contracts data. Since construction contracts may be classified as services exports, construction contracts are excluded from the calculation of Chinese ODI in this study. However, the inclusion or exclusion of construction contracts does not make a significant difference to results. ${ }^{3}$ Moreover, the AEI/HF also includes greenfield investments, but only transactions valued at or above US\$95 million.

Table 4 shows Chinese ODI in Australia based on KPMG/UniSyd data and AEI/ HF data.

Table 4. Chinese ODI in Australia: KPMG/UniSyd data and AEI/HF data (US\$ billion)

\begin{tabular}{|l|c|c|c|c|c|c|c|c|c|}
\hline & 2008 & 2009 & 2010 & 2011 & 2012 & 2013 & 2014 & 2015 & 2016 \\
\hline $\begin{array}{l}\text { Data source: KPMG/ } \\
\text { UniSyd }\end{array}$ & 16.00 & 8.50 & 3.70 & 9.30 & 11.40 & 9.19 & 8.35 & 11.10 & 11.49 \\
\hline Data source: AEI/HF & 15.78 & 9.13 & 3.34 & 9.19 & 9.24 & 8.38 & 10.03 & 10.59 & 5.26 \\
\hline
\end{tabular}

Source: Author's summary of KPMG/UniSyd and AEI/HF data.

2 Greenfield FDI projects require the establishment of new entities overseas, including offices, buildings and factories. Greenfield FDIs involve capital flow. Cross-border M\&As involve taking over or merging with the overseas enterprise's cash, assets and liabilities (UNCTAD, 2009).

3 During 2008-16, there are only (in total) US\$6.5 billion construction contracts in Australia from China, while the total non-construction Chinese ODI is worth US\$80.9 billion (AEI/HF, 2017). 
First, the comparison of Table 4 and Table 1 shows that the Chinese ODI in Australia, as indicated by data compiled by research institutions, is generally much higher than what the official data may suggest (also note that Table 4 is in US\$ while the Table 1 is in AU\$). There are reasons for this difference. Generally speaking, the transaction values announced either through media or in the form of company announcements issued through the exchanges are contracted values. They are not necessarily equal to the real value of capital flow. It is highly likely that the investment that actually happens is lower than the contracted value considering the uncertainty of business environment. Moreover, both KPMG/UniSyd and AEI/HF data do not include reverse investment, meaning that KPMG/UniSyd and AEI/HF may potentially inflate the real value of capital flow. At the same time, both KPMG/UniSyd and $\mathrm{AEI} / \mathrm{HF}$ data do not include earning reinvestment, meaning that KPMG/UniSyd and AEI/HF may potentially deflate the real value of capital flow. However, the net effect, which is difficult to evaluate, should be marginal compared with the difference between contracted value and real value.

Second, the results from KPMG/UniSyd and AEI/HF during 2008-2015 are in fact very similar. However, since KPMG/UniSyd datasets have a lower criterion of inclusion (only US\$5 million) than AEI/HF, KPMG/UniSyd results should be higher than AEI/HF results. Since KPMG/UniSyd did not disclose detailed methodology of data collection, including whether construction contracts were included, the question of why KPMG/UniSyd and AEI/HF results are so similar will remain a mystery.

In fact, a reasonable approach of collecting M\&A data is to retrieve original data from data vendors including Dealogic, ThomsonOne and MergerMarket. Since these three data vendors often provide repetitive data items, the combined results will first need to be cleaned. After that, the cleaned datasets will become the foundation of Chinese ODI data (excluding greenfield investment) for further updating or upgrading.

\section{FIRB data}

FIRB data reveals a stunning picture of Chinese ODI in Australia. In 2015-16, China was the largest source of foreign investment approvals by both value and number. The value of approvals for Chinese investors was AU\$47.3 billion in 2015-16, representing 26 per cent of the total value of approvals (FIRB, 2017). However, these figures are too inflated as a measure of Chinese ODI in Australia.

First, the statistics contained in the FIRB Annual Report reflects investors' intentions (not actual purchases) to acquire Australian assets. There are substantial differences between these statistics on proposed investments and actual investment 
flows. FIRB itself also recommends the audience use ABS data, which more comprehensively reflect investment transactions between residents of Australia and non-residents (FIRB, 2017).

Second, FRIB data are based on the assumption that investment funds will be sourced from overseas. The extent to which approved investment proposals will actually be funded from outside of Australia and result in foreign capital inflows depends not only upon whether they are implemented, but also upon the proportion that is financed from foreign sources. The proposed funds to be invested may be contributed by Australians.

Third, FIRB data may include some transactions that do not actually proceed. They include proposals that are approved in a given year but that are not actually implemented in any year; approvals for multiple potential acquirers of the same target; approvals for shares or units where only a portion of the intended shares or units may be acquired.

Fourth, FIRB also points out that policy and legislative change can have a considerable impact on the continuity of data. Changes in administrative practice and foreign investment application requirements have also impacted year-to-year data comparability.

Fifth, there are some factors that especially skew Chinese ODI measurement in FIRB data:

- First, while the acquisitions of interests from foreign government investors in a few sectors in Australia need special approval from FIRB, ${ }^{4}$ SOEs account for a large fraction of Chinese ODI in Australia (for example, over half of Chinese project value was from SOEs in 2016, and this fraction is even higher before 2016 (KPMG/UniSyd, 2013-2017: issue 2017)). This especially increases the significance of Chinese investment in FIRB data.

- Second, Chinese investors have a special interest in the real estate sector. Under Australia's foreign investment framework, foreign persons generally need to apply for foreign investment approval before purchasing residential real estate in Australia. This also improves the significance of Chinese investment in FIRB data.

4 See the Foreign Acquisitions and Takeovers Act 1975 (Cwth) (available here: www.legislation.gov.au/Details/ C2016C01144) and the Foreign Acquisitions and Takeovers Regulation 2015 (Cwth) (available here: www.legislation. gov.au/Details/F2015L01854). 


\section{Conclusions}

Many people are keen to know 'how much Chinese investors have invested in Australia' just as asked in this paper's title. A number of institutions try to provide answers. Unfortunately, these answers do not completely resolve the question, but, to some extent, create more confusion. This study provides a brief review on the methodologies employed by these institutions to conduct data collection. Table 5 presents a summary of main findings.

Table 5. A summary of Chinese ODI data

\begin{tabular}{|c|c|c|c|}
\hline Data source & Scope of coverage & Nature of data & Size \\
\hline ABS & $\begin{array}{l}\text { M\&A and JV deals with at least } 10 \% \\
\text { voting rights + greenfield projects }\end{array}$ & \multirow[t]{2}{*}{ real value of direct capital flow } & \multirow{5}{*}{ 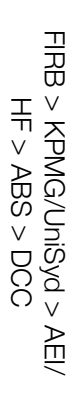 } \\
\hline DCC & $\begin{array}{l}\text { M\&A and JV deals with at least } 10 \% \\
\text { voting rights + greenfield projects }\end{array}$ & & \\
\hline KPMG/UniSyd & $\begin{array}{l}\text { M\&A and JV deals valued not less than } \\
\text { US } \$ 5 \text { million + greenfield projects(?) }\end{array}$ & \multirow[t]{2}{*}{ contracted value of deals } & \\
\hline $\mathrm{AEI} / \mathrm{HF}$ & $\begin{array}{l}\text { M\&A and JV deals valued not less than } \\
\text { US\$95 million + greenfield projects }\end{array}$ & & \\
\hline FIRB & $\begin{array}{l}\text { Foreign proposed investment that } \\
\text { needs approval }\end{array}$ & value of proposed transactions & \\
\hline
\end{tabular}

Source: Author's summary of datasets.

First, ABS and DCC data only measure Chinese ODI in Australia that comes directly from China. The real value of Chinese capital flow in Australia should be greater than ABS/DCC data. Second, researchers should be cautious when using $\mathrm{KPMG} /$ UniSyd data, since no detailed description on data collection and analysis is disclosed. Furthermore, KPMG/UniSyd and AEI/HF data only measure contracted value, which is may be higher than the real value of capital flow. Third, it can be misleading to use FIRB data to measure Chinese ODI in Australia, as it offers only the value of proposed investment, and there are a number of other factors that affect the measurement.

\section{References}

ABS (2016). International Investment Position, Australia: Supplementary Statistics, 2016 (Cat. No. 5352.0).ABS. Retrieved from: www.abs.gov.au/ausstats/abs@.nsf/exnote/5352.0

AEI/HF (2017). China Global Investment Tracker [Data set and online tool]. Retrieved from: www.aei.org/china-global-investment-tracker/ 
Australian Government (2017). A foreign investment regime that facilitates investment and protects the national interest (2017-18 Budget Papers-Fact Sheet). Retrieved from: www.budget.gov.au/2017-18/content/glossies/factsheets/download/FS_Foreign Investment.pdf

Callick, R. (2017). Chinese investment in Australia soars to \$4.8bn. The Australian, 27 February. Retrieved from: www.theaustralian.com.au/business/economics/chineseinvestment-in-australia-soars-to-48bn/news-story/1e3503d4940f69366e583448bf5fe0b7

DCC (2010). 对外直接投资统计制度 [The Statistics Rules of China's Outward Direct Investment]. December. Retrieved from: images.mofcom.gov.cn/hzs/ accessory/201102/1297930121981.pdf

Drysdale, P. (2011). A new look at Chinese FDI in Australia. China \& World Economy, 19(4): 54-73. doi.org/10.1111/j.1749-124X.2011.01250.x

Drysdale, P., Armstrong, S. \& Thomas, N. (2016). Chinese ODI and the Need to Reform Australia's Foreign Investment Regime (EABER Working Paper No. 25459). 2016. Retrieved from: www.eaber.org/system/tdf/documents/EABER\%20Working\%20Paper \%20117\%20Drysdale_0.pdf?file=1\&type=node \&id=25459\&force=

FIRB (2017). Annual Report 2015-16. Commonwealth of Australia: cdn.tspace.gov.au/ uploads/sites/79/2017/04/1516-FIRB-Annual-Report.pdf

Hatzvi, E., Meredith, J. \& Nixon, W. (2015). Chinese Capital Flows and Capital Account Liberalisation. RBA Bulletin, December, 39-48. Retrieved from: www.rba.gov.au/ publications/bulletin/2015/dec/pdf/bu-1215-5.pdf

IMF (2009). Balance of Payments and International Investment Position Manual (Sixth Edition). IMF. Retrieved from: www.imf.org/external/pubs/ft/bop/2007/bopman6.htm

KPMG/UniSyd (2013-2017). Demystifying Chinese Investment in Australia [Report series, issues 2013, 2014, 2015, 2016 and 2017]. Demystifying Chinese Investment in Australia: demystifyingchina.com.au/

Liu, K. (2016). Chinese Renminbi after 11 August 2015. JASSA: The Finsia Journal of Applied Finance, 4, 11-20.

Prasad, E. \& Wei, S.-J. (2007). The Chinese approach to capital inflows: Patterns and possible explanations. In S. Edwards (ed.), Capital Controls and Capital Flows in Emerging Economies: Policies, Practices and Consequences (pp. 421-80). University of Chicago Press. doi.org/10.7208/chicago/9780226184999.003.0010

Scott, J. (2017). Chinese investment in Australia surged 11.7 per cent to $\$ 15.4 \mathrm{~b}$ last year: report, The Sydney Morning Herald, 1 May. Retrieved from: www.smh.com.au/ business/chinese-investment-in-australia-surged-117-per-cent-to-154b-last-year-report20170501-gvw8pc.html 
Tan, S.-L. (2017). Chinese investment in real estate grows to \$32b: FIRB. Financial Review, 9 May. Retrieved from: www.afr.com/real-estate/chinese-investment-in-real-estategrows-to-32bn-firb-20170509-gw0sla\#ixzz4hPUa2uPw

UNCTAD (2009). UNCTAD Training Manual on Statistics for FDI and the Operations of TNCs. Volume I: FDI Flows and Stocks. United Nations Conference on Trade and Development Division on Investment and Enterprise. Retrieved from: unctad.org/en/ Docs/diaeia20091_en.pdf 
This text is taken from Agenda, Volume 25 - Number 1, 2018, edited by William Coleman, published 2018 by ANU Press, The Australian National University, Canberra, Australia.

doi.org/10.22459/AG.25.01.2018.03 